\title{
Cultura e imágenes de las ciudades de Andalucía, siglos XIII-XVII ${ }^{1}$
}

\author{
Culture and images of Andalusian cities, 13th-17th centuries
}

\author{
Andrea Mariana NAVARRO \\ Universidad Nacional de Tucumán \\ andrea1816@yahoo.es
}

\begin{abstract}
Resumen
Imágenes mentales sobre las ciudades de Andalucía entre los siglos XIII y XVII y su incidencia en la formación de identidades culturales. Estudio sobre los siguientes aspectos: emplazamientos topográficos, estructuras materiales, caracterización de los habitantes y sus costumbres, vida cotidiana, prácticas cívico-religiosas, políticas y económicas, ceremonias y fiestas. Evolución de todos estos elementos, en los que ese expresó un sistema de valores, la capacidad de percepción y las diversas ideas de los observadores españoles y extranjeros, la conciencia de sí mismas que tuvieron las élites ciudadanas y sus ideales y aspiraciones como grupos sociales dominantes, el papel de la monarquía y de la Iglesia, tanto en las épocas de auge (siglos XV y XVI) como en las de decadencia (siglo XVII).
\end{abstract}

Palabras clave: Ciudades de Andalucía. Imágenes urbanas. Paisajes urbanos. Religiosidad. Cultura urbana. Orígenes míticos

\begin{abstract}
Mental images of the cities of Andalusia from the 13th through the 17th centuries and their effect on the formation of cultural identities. The following aspects will be studied: topographical locations; material structures; the characterization of inhabitants and their customs; daily life; civic, religious, political and economic practices; ceremonies and festivities. The evolution of all of these elements, which express systems of values, perceptive capabilities, and the diverse ideas of Spanish and foreign observers, the self-consciousness of urban elites and their ideals and aspirations as dominant social groups, the role of the monarchy and the Church, in periods of rise (15th and 16th centuries) as well as those of decline (the 17th century).
\end{abstract}

Keywords: Andalusia. Cities. City images. Urban landscapes. Religiosity. Culture. Urban historiography

Sumario: 1. Introducción. 1.1. El tema de estudio. 1.2. Objetivos 1.3. Metodología de la investigación 1.4. Hipótesis 2. El espacio exterior de las ciudades. 3. Imágenes de ciudades fortificadas. 4. El paisaje urbano. 5. Las ciudades y sus actividades económicas. 6. Representaciones de las sociedades urbanas. 7. Las ciudades: centros de gravedad de la vida política. 8. Expresiones de la religiosidad en la cultura urbana. 9. Espacios y tiempos de las fiestas. 10. Retornos al pasado. Origenes miticos y recuerdos de Roma. 11. Conclusiones

${ }^{1}$ Resumen de tesis doctoral dirigida por el Prof. Dr. Miguel Ángel Ladero Quesada, Catedrático de Historia Medieval, presentada a examen el 11 de febrero de 2011 en la Facultad de Geografía e Historia de la Universidad Complutense (2 vol., 1200 p.). 


\section{INTRODUCCION}

\subsection{EL TEMA DE ESTUDIO}

"Cultura e imágenes de las ciudades de Andalucía, siglos XIII-XVII" se inscribe en la intersección de la Nueva Historia Cultural y la Historia Urbana. La investigación se ha centrado en las imágenes e imaginarios urbanos andaluces y en la incidencia que éstos tuvieron en la conformación de sus identidades culturales, circunscribiendo su análisis a las ciudades de realengo de la región: Sevilla, Carmona, Jerez de la Frontera y Ecija, integradas en el reino de Sevilla; Jaén, Ubeda, Baeza y Andújar, comprendidas en el reino de Jaén, y Córdoba como ciudad capital de su reino.

La temática respondió al interés por el estudio del mundo urbano en la Corona de Castilla, y la elección del ámbito espacial se debió a que Andalucía tuvo entidad y personalidad propia a partir de la Reconquista cristiana, cuando se definió con rasgos peculiares que la diferenciaron de otras regiones por su más reciente incorporación y su condición de nueva frontera. En razón de que a lo largo de los siglos bajomedievales dichas comunidades urbanas desempeñaron un papel central en la defensa de los territorios del sur de España y en la conquista del reino de Granada, y que a partir del final del siglo XV tuvieron una influencia decisiva como principales ejes articuladores de vínculos demográficos, económicos, religiosos y culturales con los dominios españoles en América, procesos que llevaron consigo la reproducción de sus modelos de ciudades que dejaron su impronta en la organización y configuración de nuevos espacios territoriales y socio-culturales.

El marco temporal de estudio comprendió los siglos XIII al XVII, período que permitió valorar imágenes urbanas y rasgos de identidad de sus comunidades en la larga duración e identificar etapas: la de la Reconquista cristiana con la repoblación y la nueva organización territorial (s. XIII-XIV); el momento de esplendor en el que adquirió mayor centralidad la región andaluza en el imperio español (s.XV-XVI) y la etapa de decadencia (s. XVII).

\subsection{OBJETIVOS}

Esta investigación se propuso analizar de qué manera las sociedades urbanas crearon sus propias representaciones, forjaron imágenes que resultaban de la imbricación de la "ciudad real" con la "ciudad imaginada", que no pueden ser concebidas de manera puramente objetiva, como simples reflejos de la realidad física y material, sino como realidades subjetivas y simbólicas, soñadas por sus habitantes, dirigentes y por "otros" -españoles y extranjeros-; elaboradas a partir de sus percepciones, impresiones, de las sensaciones visuales, auditivas y olfativas que afectaban a la imagen global, de los pensamientos, sentimientos, intereses, de las experiencias, vivencias, de los sistemas de valores e incluso de utopías.

Tuvo en cuenta imágenes impuestas, instituidas, sugeridas, difundidas, promovidas por clérigos, nobles, oligarquías urbanas, historiadores, cronistas, viajeros, urbanistas y artistas, en distintos contextos históricos y con fines concretos. 
Se planteó mostrar las diversas modalidades a través de las cuales se forjaron, reprodujeron y renovaron imágenes e imaginarios urbanos, las formas de sentir, pensar y creer; determinar cómo se produjo la transmisión de imágenes, las diversas formas y circuitos que se emplearon para su difusión, así como los instrumentos de persuasión, inculcación de valores y creencias, de control, dominación de los imaginarios sociales y su vinculación con la capacidad de los distintos niveles de poder (la monarquía, las instituciones eclesiásticas y las oligarquías urbanas) para producir un impacto variable en los comportamientos y en las mentalidades. En ese sentido, se analizó el papel que jugaron los imaginarios sociales en las mentalidades y en las prácticas colectivas, sus vínculos con los modos de vida y la cultura urbana.

\subsection{METODOLOGÍA DE LA INVESTIGACIÓN}

En primer lugar, definimos los conceptos que delimitaron nuestro estudio. Tomamos la noción de imagen en su sentido antropológico, como forma de representación mental producto de la imaginación, de la capacidad de moldear las percepciones de acuerdo a intereses de la persona o de la colectividad que las construyó, bajo el impulso del dinamismo psíquico y la influencia del medio físico, social y cultural. Hicimos referencia al imaginario social porque nos centramos en la producción de representaciones globales de la sociedad, de todo aquello que se relaciona con ella, y tratamos de contemplarlo como fenómeno colectivo. Tomamos también la noción de imagen en el sentido en que ha sido estudiada por la historia del arte y la historia de las imágenes, para ello consideramos el material visual en su variedad de formas y tipos, en sus diferentes soportes.

Entendimos la identidad colectiva como un concepto que ponía el acento en los rasgos esenciales que permitían definir la pertenencia a una comunidad y marcar su territorio y las fronteras para diferenciarse de "otros". En este sentido, el concepto de imaginario constituyó una categoría clave porque incluyó no sólo una manera de interpretar el mundo, sino una manera de verse, imaginarse, pensarse, en este caso, cómo se vio la sociedad urbana andaluza a sí misma (cómo elaboró su auto-representación) y cómo la vieron "otros".

Por último, el análisis de la Cultura urbana comprendió los sistemas de creencias, valores, comportamientos, prácticas cotidianas, cívico-religiosas, políticas, económicas, costumbres, rituales, ceremonias, aspectos lúdicos y festivos de las sociedades. Todas ellas hicieron reconocibles las identidades colectivas al exhibir una manera de ser en el mundo, al hacer visible un tipo particular de existencia de una comunidad urbana.

En segundo término, para llevar a cabo la comparación entre las ciudades nos basamos en un vasto corpus de fuentes -en su mayoría éditas- para contrastar visiones, formas de representación, contradicciones entre las construcciones teóricas, la realidad y las prácticas, y brindar un panorama lo más completo posible, desde una perspectiva amplia. En el análisis incluimos fuentes legales, narrativas, historiográficas, literarias, iconográficas y la planimetría. 


\subsection{HIPÓTESIS}

Las ciudades, como espacios creadores, colectivos e históricos producen significaciones que constituyen una historia de sus representaciones, en ese sentido, consideramos que los discursos narrativos, literarios e iconográficos sobre las ciudades conservaron una estructura formal conforme a un esquema general que contempló ciertos elementos impuestos por el tipo urbano. Esos elementos fundamentales que afectaron de manera estable el concepto-idea general sobre las ciudades fueron: el emplazamiento topográfico, la estructura material-física, el carácter de sus habitantes. No obstante, la elaboración de sus representaciones se fue particularizando al remitirse a sensaciones, percepciones, vivencias, experiencias, creencias e intereses individuales y colectivos. Escaparon a la rigidez de las descripciones, y aunque mantuvieron ciertos rasgos constitutivos tradicionales, incluyeron detalles cada vez más significativos que las hicieron reconocibles e identificables. De esta forma, consideramos que no sólo las realidades urbanas evolucionaron, sino que los puntos de vistas y las miradas sobre ellas cambiaron en distintos contextos, y que en la construcción cultural de sus representaciones intervinieron la gestión gubernativa, la influencia del poder monárquico y eclesiástico, una forma de vida propia de las sociedades de frontera, las mentalidades, creencias y valores religiosos, los usos, prácticas y costumbres de sus habitantes, que en cada caso aportaron un matiz diferenciador del hecho urbano y de sus comunidades.

En la elaboración de imágenes se articularon dos formas -relacionadas y complementarias- de concebirlas: una la definió como estructura urbanística y otra como comunidad cívica y religiosa. Ambas fueron inseparables porque toda ciudad fue proyección de los imaginarios sobre el espacio.

A través de los imaginarios sociales una colectividad designó su identidad, definió sus fronteras y relaciones con "otros", elaboró una representación de sí misma, distribuyó los papeles y las posiciones sociales y fijó modelos formadores para los ciudadanos.

El imaginario social fue una pieza clave de los dispositivos de control de la vida colectiva y del ejercicio de poder de sus gobernantes, cuyos valores se tradujeron en normas para el ordenamiento general de las ciudades, las formas de sociabilidad y la convivencia cotidiana.

El imaginario religioso, coherente con la cultura y las creencias cristianas, recreó analogías entre el espacio urbano y el de la salvación al dotar a sus comunidades de una serie de elementos simbólicos para la protección espiritual de sus habitantes y la sacralización de su espacio, poniéndolos bajo la tutela eclesiástica.

La simbología, las ceremonias y las fiestas fueron modeladoras de los imaginarios colectivos y de opiniones, y como expresiones culturales produjeron un sistema específico de representaciones. Ofrecieron un gran repertorio de imágenes, las primeras articularon ideas, imágenes y modos de acción, las segundas constituyeron un decorado y un soporte a la propaganda de los poderes y de los grupos sociales participantes, a los dispositivos simbólicos, a los rituales, y fueron instrumentos eficaces para influir, orientar los sentimientos y sensibilidades de las sociedades. Especialmente estas últimas pueden interpretarse como un modelo de la realidad, cuando 
reflejaban con relativa fidelidad la concepción cultural que una sociedad tenía de sí, o como un modelo para la realidad, cuando se reflejaba a través de ella no tanto lo que era, sino lo que debería ser o le gustaría ser.

\section{EL ESPACIO EXTERIOR DE LAS CIUDADES}

La imagen de las ciudades no se circunscribió al espacio delimitado por sus muros, sino que comprendió el marco natural donde se emplazaron: el entorno topográfico. La sociedad medieval y moderna poseyó plena conciencia de la importancia de la articulación entre ciudad-campo porque en ella se fundaba la complementariedad económica y se asentaba la jerarquía de la primera. En el caso andaluz, ese paisaje diferenciado y con identidad propia, inspiró hasta el siglo XVII valoraciones que remitían siempre a la calidad de las ciudades que se reflejaron en la defensa de poderes jurisdiccionales urbanos sobre sus alfoces o términos, en su identificación con todas las características de los espacios míticos y con los tópicos del locus amoenus, y en la creencia de la superioridad de un modelo agrario con capacidad de movilizar sensibilidades colectivas: sentimientos de arraigo, de anhelo de volver a vivir en sus tierras, de curiosidad y placer por el descubrimiento.

Dichas consideraciones tuvieron prolongada vigencia y consenso ya que las encontramos reproducidas en la visión y en la opinión de distintos colectivos. Procedieron de los testimonios de las más antiguas civilizaciones que encontraron excelentes condiciones para vivir en sus tierras. Los historiadores españoles los compartieron, se apoyaron en el género de lo "maravilloso" -cuyos tópicos tuvieron enorme éxito en la cultura popular, medieval y moderna-, para recrear "tierras de promisión" y "jardines de deleite y recreación", y buscaron en mitos y leyendas modelos y correspondencias con espacios imaginados y perfectos, como los Campos Elíseos. Esas asociaciones resultaron significativas sobre todo en el contexto de los siglos XV, XVI y XVII, porque expresaron la importancia de los espacios circundantes y las pretensiones urbanas legitimadoras y reivindicadoras de sus derechos sobre un hinterland que estaba en peligro de ser enajenado o de perderse en manos de la nobleza. Asimismo, artistas y viajeros que recorrieron y conocieron su realidad directamente, sintieron también alta estima por las tierras andaluzas, lo que se comprueba por la elevada concurrencia de españoles y extranjeros que dejaron numerosas descripciones sobre ellas.

En la configuración de imágenes urbanas, la valoración económica de los alfoces o términos tampoco estuvo ausente ya que su riqueza también procedía de las tierras. Un rico caudal de impresiones aportó información acerca de la calidad de los entornos rurales, así cobró relieve y sentido que las fuentes enfocaran su interés en una selección de temas que tenían relación con la recaudación de rentas, los beneficios económicos reportados a los grandes propietarios por sus negocios agrícola-ganaderos, las condiciones de la producción para garantizar el abastecimiento urbano consistente en todo género de mantenimientos, y el reconocimiento de las ciudades más allá de sus muros, gracias a la comercialización y exportación de sus productos. Esa conjunción contribuyó a forjar la imagen de una "tierra copiosa y viciosa", expresión muy difundida en las fuentes de la Edad Media y la Edad Moderna, que sintetizaba 
bien la "extrema bondad" del espacio agrario andaluz, que perduró por lo menos en las mentalidades colectivas hasta el siglo XVII, cuando comenzaron a mostrarse los ecos de la hegemonía perdida.

Los recursos hídricos no fueron ajenos a las realidades y construcciones de sus representaciones. Excepto en períodos de crecidas peligrosas en que las ciudades tuvieron que defenderse de sus riadas, los cursos fluviales tuvieron en ámbitos rurales efectos benéficos vinculados a actividades agrícola-ganaderas, a la consiguiente concentración de industrias, y por ende, de población e intercambio de productos y servicios. El Guadalquivir por ejemplo, constituyó un factor de primer orden al hacer que Sevilla pudiera capitalizar para su desarrollo y crecimiento todas las ventajas que le ofrecía su puerto, convirtiéndose en capital regional y metrópoli internacional hasta el siglo XVII.

Respecto a los efectos en el interior de las urbes, los gobiernos municipales ejercieron una minuciosa política intervencionista para mejorar los servicios urbanos con la construcción de fuentes y pilares que aportaban mayor amenidad, frescura, limpieza, salubridad y ornato. Por estas razones, en todo discurso se subrayó el carácter funcional, práctico, utilitario y simbólico del agua dentro y fuera del espacio urbano, por ello ha sido considerada un "bien público" y un elemento clave para elaborar conceptos e imágenes.

\section{IMÁGENES DE CIUDADES FORTIFICADAS}

Castillos, fortalezas, murallas, puertas y alcázares constituyeron otros elementos fundamentales en la definición y caracterización de las ciudades. Fueron objeto de descripciones parcialmente estereotipadas pero no estables, porque las experiencias de la guerra y de la paz, de las luchas fronterizas y de las relaciones políticas entre monarquía-nobleza y ciudades hicieron de ellos símbolos polivalentes, cuyas significaciones fueron variando. En ese sentido, subrayamos tres dimensiones, la utilitaria, la creadora de acciones y la simbólica, y pusimos de relieve que la desaparición de funciones tradicionales y la sustitución por otras nuevas dieron cuenta del paso de la ciudad medieval a la ciudad moderna.

Fundamentalmente la experiencia de la guerra con los musulmanes incidió en la construcción de la arquitectura militar con fuerte poder de persuasión. Esa fuerte carga simbólica también se puso de relieve en los escudos de armas de las ciudades donde castillos, torres, fortalezas y alcázares estuvieron representados, y en el imaginario religioso, porque la defensa sagrada proporcionada por las imágenes marianas en sus puntos estratégicos (puertas, murallas y alcázares) imprimió en los cristianos la creencia de estar doblemente amparados.

Por lo general toda representación urbana llevó consigo la imagen de un espacio cerrado, inexpugnable, que demostraba eficacia para resistir los embates, haciendo que el arte de la guerra se convirtiera en un ejercicio intelectual que obligaba a un mayor esfuerzo humano, económico y técnico para el asedio, o a confiar en el milagro y la intervención divina para la conquista de las ciudades. Así, gran parte de las impresiones que derivaron de las estructuras amuralladas fueron portadoras de una idea que amalgamó lo real con lo ideal o imaginario. 
Las experiencias de la vida política andaluza mostraron también otras significaciones de castillos, torres, fortalezas y alcázares. Convertidos estos en tenencias de la nobleza señorial y urbana y en puntos de apoyo de bandos-linajes o bandosparcialidades, representaron un peligro para la estabilidad interna de las ciudades. Especialmente durante las ceremonias de recibimiento y entradas reales, murallas y puertas potenciaron su dimensión simbólica, pues allí se desarrollaron una serie de actos, ritos y gestos que fueron referentes de distintas fórmulas de diálogo político entre el gobierno urbano y el poder monárquico, ya que se usaron para expresar las tensiones, las resistencias, la sumisión o el acatamiento.

Finalizada la guerra de frontera, la imagen de ciudades-fortalezas perdió primacía al imponerse otra, la de las "ciudades abiertas", porque las comunidades urbanas buscaron comunicarse mejor mediante el ensanchamiento y la apertura de puertas y postigos para facilitar la circulación de mercancías y controlar la fiscalidad vinculada al comercio, reconstruyéndose con carácter monumental y mayor ornato, para transformarse en el nuevo emblema urbano.

No obstante, las ciudades no renunciaron a la premisa de permanecer "custodiadas" y para ello tomaron medidas preventivas que garantizaran la seguridad de sus habitantes a través de la vigilancia policíaca de murallas y puertas durante determinadas horas del día y la noche, o dispusieron medidas de aislamiento si era necesario, con la intervención de autoridades sanitarias, cuando el peligro de propagación de pestes las amenazaba.

\section{EL PAISAJE URBANO}

Las construcciones edilicias con sus formas arquitectónicas, espacios públicos (calles y plazas) y privados (casas y palacios) también ayudaron a configurar las imágenes urbanas. Hemos subrayado la interrelación entre estructuras materiales y sociales al reconocer a aquellas como construcciones simbólicas, como expresiones de formas de vida de los habitantes y representaciones de sus relaciones jerárquicas. En ese sentido, las imágenes de las ciudades han sido contempladas como proyección del carácter y personalidad de las sociedades andaluzas, de sus costumbres y prácticas, como reflejos de su cultura.

La conciencia urbana y ciudadana alentada por sentimientos de orgullo cívico se expresó en dos tipos de imágenes: la que resaltó la asimilación de modelos de la cultura aristocrática en el imaginario urbano, y la que buscó vincular grandezas y excelencias urbanas a la herencia romana para borrar todo recuerdo y vestigio del pasado islámico.

Frente a esas construcciones teóricas sobre las ciudades andaluzas, pueden reconocerse otras representaciones. Una procede de los gobiernos municipales que transmitieron una visión más realista y crítica de las ciudades tratando de resolver los problemas cotidianos, pero plasmaron también en ellas cómo querían o aspiraban las élites gobernantes que fuesen las ciudades, traduciendo en normas asuntos centrales como el orden, la limpieza, la higiene, la belleza y el ornato. Precisamente, entre los siglos XV-XVII se observó una tendencia renovadora del espacio urbano con objetivos prácticos, utilitarios y estéticos, por eso entendemos que la imagen urbana, su 
aspecto y fisonomía no puede escindirse de la acción gubernativa. La calidad, "honra" y "ennoblecimiento" de las ciudades estuvo condicionada por ella, de la misma manera que de la eficacia en la gestión de los funcionarios dependió la imagen de su "buen o mal gobierno".

El campo de actuación que aludimos comprendió aspectos diversos: la reparación de obras que estaban en mal estado, la construcción y mejoramiento edilicio, sobre todo de las principales instituciones civiles (ayuntamientos, audiencias, cárceles, hospitales, colegios, universidades, lonjas, pósitos y alhóndigas) que se extendieron en el plano urbano. Con ellas, las comunidades contaron con una infraestructura necesaria para organizar la vida ciudadana. Enorme incidencia tuvieron esas iniciativas en la nueva configuración de los espacios, pues sus costosas e insignes fábricas jerarquizaron y "ennoblecieron" los puntos neurálgicos donde fueron emplazadas, zonas donde se centralizaban funciones político-administrativas, así como las que marcaban el compás de la actividad comercial y financiera. Asimismo, fueron significativas por el carácter monumental con que se concibieron, lo que permitió que las construcciones elevadas por sus torres, dominaran el paisaje, traduciendo en su escala la relación de poder y autoridad ostentada por las instituciones, y pudiendo ser vistas desde fuera de los muros y a la distancia.

Las iniciativas urbanísticas tuvieron también su correlato en el mejoramiento viario, con el fin de que las calles estuvieran más transitables, bien comunicadas y limpias -aunque la ampliación y pavimentación se hizo de manera selectiva-; en la creación de numerosos espacios amplios como las plazas, que fueron escenarios embellecidos para la práctica de nuevas formas de sociabilidad de los ciudadanos (fiestas cívicas, celebraciones religiosas, juegos, entretenimientos) y en la recuperación y cuidado del espacio público. Ese compendio de acciones políticas tuvo estrecha relación con la creación de espacios y ambientes más propicios para la vida de los habitantes, convirtiéndolos en lugares más ordenados, cómodos, bellos, limpios y saludables.

Asimismo, la nueva imagen de las ciudades devino del patrimonio inmobiliario (casas y casas-palacios) que completó el mejoramiento urbanístico. Una socio-topografía lo puso en evidencia: modestos vecinos se ocuparon de hacer más agradable el exterior y el interior de sus viviendas. Sin embargo, esa tendencia fue superada ampliamente por los "ciudadanos más honrados": alto clero, nobleza, caballeros y grandes mercaderes. Sus residencias crearon un ambiente placentero, tradujeron el poder y prestigio que gozaban sus propietarios, ganaron verticalidad, se dotaron de mayor riqueza decorativa y de materiales nobles, incorporaron el arte renacentista, además de la heráldica en sus fachadas, haciéndose claramente visibles en la ocupación del espacio urbano, y notorio el afán de ostentación de numerosos linajes.

Una consecuencia importante de esa transformación urbana fue la sustitución de la herencia hispano-musulmana, proceso que fue posible en un contexto de paz y en una coyuntura favorable, de florecimiento de las economías locales, de expansión demográfica y de frecuentes visitas regias que exigieron mayores reformas. La visión de los viajeros corrobora esa imagen renovada del urbanismo, mediante comparaciones que dieron cuenta de las semejanzas de las ciudades andaluzas con otras ciudades europeas. 
La otra imagen a la que aludimos pone de relieve que el aspecto que presentaron las ciudades dependió de las prácticas, hábitos y costumbres de sus habitantes, en este punto radicaron las verdaderas limitaciones de las gestiones municipales. En gran medida el descuido, deterioro y desorden del espacio público fue responsabilidad de sus vecinos y moradores, sobre todo porque determinados oficios particularmente contaminantes se mostraron poco dispuestos a observar las ordenanzas municipales. En ese sentido, las fuentes reflejan casi siempre el mismo panorama: la imagen antihigiénica de las ciudades, lo que nos lleva a concluir que la cultura de la transgresión pareció dominante, faltó toma de conciencia por parte de la población para cuidar el espacio urbano.

\section{LAS CIUDADES Y SUS ACTIVIDADES ECONÓMICAS}

Las actividades económicas (comercio y manufactura) también incidieron en la configuración de las imágenes urbanas, en el crecimiento y desarrollo de las ciudades, en la diferenciación de sus espacios y en los comportamientos y prácticas de sus habitantes.

Más que las ferias -que tuvieron incidencia limitada y éxito relativo en la articulación de espacios mercantiles que dieran centralidad a las ciudades andaluzasfueron los mercados los que contribuyeron a la formación de varios polos donde se concentraron actividades destinadas a la producción, comercialización y abasto.

Como centros de producción manufacturera, tres ramos destacaron en la economía de las ciudades andaluzas, por concentrarse en ellos la ocupación de numerosos vecinos y pobladores y cubrir la demanda del mercado regional e internacional (sobre todo de las Indias Occidentales): la industria textil (de nivel modesto), el trabajo del cuero (de excelente calidad) y las relativas a la actividad marítima, especialmente en ciudades mercantiles, como Sevilla. Las fuentes y la bibliografía han ayudado a delinear una cronología de su desarrollo: la etapa próspera del siglo xvi y la época de declive y estancamiento, en la centuria siguiente, siglo XVII.

Las imágenes de las ciudades como centros de consumo se han visto desde la óptica de las prácticas políticas. Un asunto de interés general y de primer orden en las preocupaciones de las autoridades municipales fue el abastecimiento. En ese sentido, una exhaustiva reglamentación tendente a garantizar el aprovisionamiento de los habitantes ha dado cuenta no sólo de las circunstancias difíciles provocadas por las crisis de subsistencias, sino del marcado intervencionismo para proteger la producción local y combatir el acaparamiento y especulación sobre los artículos de consumo básico; establecer precios razonables y justos; vigilar la reventa de regatones y regateras; controlar la apertura de tiendas y establecimientos de venta; prohibir la salida de algunos artículos hasta que la población se encontrara bien provista; vigilar su peso y calidad; y disponer de un correcto funcionamiento de pósitos. Todas esas medidas generales fueron necesarias porque condicionaban la paz y estabilidad urbana, dado que situaciones provocadas por carestías, escasez y encarecimiento eran susceptibles de generar bullicios, alborotos y desórdenes.

Otras imágenes sobre la vida económica urbana han procedido de las prácticas de los vecinos y moradores involucrados en la producción y comercialización Ofi- 
cios relacionados con la provisión y suministro de alimentos básicos, como los carniceros, pescaderos, panaderos, molineros, vinateros, taberneros y mesoneros, fueron destinatarios de numerosas ordenanzas. Estos rubros claves en el abastecimiento de las ciudades, estuvieron en la mira como infractores pues abundan las referencias que denuncian acciones impropias y deshonestas de uso común y frecuente, y leyes que trataron de remediar operaciones fraudulentas para que no dañaran a los consumidores. El mundo laboral y las prácticas económicas dejaron al descubierto conductas irregulares a las que fueron propensos productores, vendedores, intermediarios, artesanos, ese panorama deja entrever que la cultura del fraude y del engaño en el comercio y los tratos reportaba ganancias, y que a pesar de los riesgos de ser sancionados y de hacerse con mala fama, algunos oficios buscaron en la ilegalidad sus beneficios económicos.

También estas dos cuestiones relativas al abastecimiento y al control de las actividades productivas y comerciales resultan centrales en la consideración del "buen o mal gobierno" de las ciudades, porque el cumplimiento del orden, la justicia, legalidad de los tratos y transacciones y el control sobre la moralidad de las costumbres condicionó su imagen. Quizás hubo poco acatamiento de las normativas reales y municipales, a juzgar por las variadas expresiones que se emplearon para mostrar que ciertas prácticas provocaban "gran daño a la república"; "producían gran mengua a las ciudades"; o "perjuicio público", pero creemos que las actividades económicas constituyeron una referencia importante no sólo de las acciones de gobierno, sino de la vida de las ciudades porque el complejo juego de intereses entre artesanos, trabajadores y clientes, productores, vendedores y consumidores afectaban al bienestar de todos. Así pues, el gobierno municipal debió regir espacios y relaciones económicas apelando a normativas que hicieran cumplir actividades lícitas, honestas y justas.

Otra de las imágenes que hemos tratado da cuenta de los modelos de desarrollo urbano en la región andaluza, dentro de los cuales cabe diferenciar a Sevilla del resto de las ciudades. Gracias a la actividad comercial de su puerto - de larga tradición en su historia- $\mathrm{y}$ a las funciones financieras -impulsadas a fines del siglo $\mathrm{xv}$ - esta ciudad se convirtió en una gran metrópoli internacional y adquirió una posición privilegiada al ser capaz de articular mercados del Nuevo Mundo, Europa y Africa.

Gran parte de las percepciones e impresiones de viajeros, historiadores y cronistas giró en torno a los resultados del contacto económico y cultural entre España y América, a todo lo relativo al arribo de "nuevas gentes" (indígenas), al tráfico de mercancías, y llegada de metales preciosos, así como a los espacios donde tuvieron lugar: el puerto, la Torre del Oro, la lonja de mercaderes, la Casa de Contratación, la Casa de la Moneda, la calle de la alcaicería. En general todos remiten a las representaciones de la ciudad como "gran almacén o factoría", "el gran depósito de tesoros de Occidente", "el centro de las mercancías del mundo", "escala y receptáculo de la gran riqueza americana, sin igual en la tierra". Su acentuado carácter internacional le valió la calificación de la "Babel sevillana" por la presencia extranjera, y de una población muy heterogénea que hablaba diferentes lenguas, rasgo que la diferenció claramente de otras ciudades andaluzas. Asimismo, no faltaron testimonios gráficos sobre la intensa actividad comercial con la circulación de navíos y el desfile incesante de gentes, gremios, barcos y mercancías que se dieron allí cita. Ilustraciones de 
libros, grabados de obras de geografía, iconografías que acompañaban los relatos de viajeros sugieren el orgullo que debieron sentir los sevillanos, cuya ciudad llevaba su imagen de prosperidad, haciendo que su nombre y su fama se difundieran en todo el mundo.

\section{REPRESENTACIONES DE LAS SOCIEDADES URBANAS}

La población, tanto desde el punto de vista cuantitativo como cualitativo constituyó otro componente esencial en la construcción simbólica de las ciudades. Dos procesos le confirieron una identidad social, religiosa y cultural nueva: la repoblación cristiana de los siglos XIII y XIV y el crecimiento poblacional con sus movimientos migratorios de fines del siglo Xv hasta la segunda mitad de la centuria siguiente. En ese último trayecto, Andalucía no sólo se convirtió en la segunda región más poblada de Castilla, sino que fue una región social y culturalmente identificable que irradió una personalidad propia reconocida en Europa y al otro lado del Atlántico por sus costumbres, formas de hablar y de vida.

El conocimiento y el contacto de "otros" con los andaluces hicieron que se reafirmaran sus impresiones sobre las diferencias con poblaciones de otras localidades y regiones de España, aunque a veces las distorsiones y los prejuicios incidieron en definiciones que les fueron poco favorables. Para los propios andaluces la diferencia se fundó en las virtudes y calidades de sus ciudadanos, para demostrarlo se apoyaron en una jerarquía social y en unos valores capaces de conferir a las ciudades excelencias y grandezas. En su construcción ideal e imaginaria tuvieron fuerza determinados tópicos sobre las cualidades de los grupos privilegiados concebidos como referentes de las ciudades. La "honra urbana" se asentó así en un orden tripartito que tenía en cuenta funciones esenciales, útiles y necesarias: la defensiva por medio de las armas, la de la salvación de las almas y la educativa, acorde con criterios tradicionales como la valoración de la nobleza de sangre o "nobleza vieja", y con otros nuevos como la valoración del individualismo y el mérito.

En la imagen de las ciudades se advierte la estrecha relación que hubo entre imaginarios urbanos y aristocráticos. De ellos procedió la identificación de las ciudades como "repúblicas de las armas" y la asimilación de símbolos externos y atributos que eran propios de los grupos privilegiados, porque las ciudades construyeron su historia como si se tratara de una genealogía, reivindicaron su antigüedad; exhibieron sus títulos nobiliarios; capitalizaron la presencia de la alta nobleza y de pequeños linajes con el mejoramiento monumental y urbanístico, con sus fundaciones religiosas, pías y caritativas. Estas representaciones respondieron a una realidad patente: al despliegue del poder político y social del patriciado urbano.

Los historiadores conscientes de que la educación también podía ayudar a la construcción teórica de las ciudades, representaron a las ciudades como "madres de hijos ilustres", como "progenitoras de hombres insignes" y "encrucijadas del conocimiento que emulaban a Grecia y a Roma". Aportaron una larga lista de "intelectuales" judíos, cristianos, musulmanes, laicos y eclesiásticos capaces de incrementar la calidad de estas como centros culturales. Sin embargo, estas imágenes no tuvieron exacta correlación con la realidad andaluza, cuyos colegios y universidades tuvieron 
un desarrollo modesto, sin posibilidades de competir con los de Valladolid, Salamanca o Alcalá de Henares u otros centros educativos europeos. Distinto fue el panorama de la formación científico-técnica que trajeron aparejados los descubrimientos geográficos haciendo de Sevilla su centro, y el de la actividad editorial de las imprentas que en las ciudades andaluzas se concentraron para atender las demandas del comercio librario nacional, europeo y americano.

No se olvidó en ese esbozo general de las sociedades urbanas a las mujeres, que en los discursos de origen masculino aparecen tuteladas y custodiadas, encarnando en general todas las cualidades que se esperaban según el estamento al que pertenecieran, y a ejemplos de vida pía y devota.

En cuanto a la convivencia cotidiana, las imágenes aportadas por las fuentes dejaron entrever la contra-cara de la sociedad idealizada. Los vicios, defectos y los asuntos conflictivos de grupos marginales y privilegiados revelaron nítidamente la imagen de la contra-sociedad impulsando medidas correctivas y de disciplina en pro de la moralización de la sociedad, de la paz y el orden en las ciudades.

\section{LAS CIUDADES COMO CENTROS DE GRAVEDAD DE LA VIDA POLÍTICA}

Dos cualidades de las ciudades, el servicio y la lealtad, fueron centrales en los ideales y en las valorizaciones de la monarquía. Ambos conceptos han merecido especial atención porque de ellos dependió la firmeza de la autoridad de los soberanos, el "bien común" y la paz de los reinos, pero tampoco resultaron indiferentes a las ciudades para construir su imagen, ya que en función de ellas recibieron titulaciones que las posicionaron según grados de ennoblecimiento que llevaban consigo el ejercicio práctico, simbólico y honorífico de la preeminencia. Las fuentes narrativas e historiográficas también valoraron esos modelos de comportamiento y los tomaron como criterio de engrandecimiento de las ciudades, haciéndolos susceptibles de reconocimiento. Ambas evocaron imágenes en las que ponían de manifiesto la autoconciencia de las ciudades sobre el papel clave que desempeñaron para afirmar, legitimar la autoridad y el poder monárquico, y la necesidad de que el rey contara con ellas para gobernar y conseguir la estabilidad de los reinos.

Asimismo, las ordenanzas municipales, los ordenamientos reales y las actas capitulares constituyeron una base imprescindible para el estudio de los gobiernos urbanos, de ellos se desprende un marcado acento en el interés por asegurar el correcto funcionamiento de sus instituciones, pero también un sinnúmero de problemas como la ausencia de regidores en las reuniones del Cabildo, el acrecentamiento excesivo en sus designaciones, la extensiva práctica del acostamiento que limitaban la independencia de los funcionarios sometiéndolos a lealtades e intereses nobiliarios y señoriales, los desórdenes provocados por las luchas entre bandos-linajes. Sus disputas y enemistades dividieron a la sociedad urbana, alteraron la vida política, dieron lugar a que estuvieran fuertemente mediatizadas por la intervención monárquica --con la generalización del corregimiento- para resolver problemas locales, corregir la gestión administrativa y poner término a las contiendas y escándalos de bando-linajes. 


\section{EXPRESIONES DE LA RELIGIOSIDAD EN LA CULTURA URBANA}

Las expresiones de religiosidad han sido también componentes esenciales en la definición de las identidades de las comunidades. La trama parroquial, la fundación de iglesias, ermitas y santuarios, conventos y monasterios materializaron la influencia eclesiástica y religiosa que afirmaban el carácter de la "ciudad cristiana" y el dominio de la fe católica, recordando que los espacios pertenecían a Dios y estaban sacralizados. Asimismo, el imaginario colectivo recreó analogías entre el espacio urbano y el espacio de la salvación, pues en los recintos amurallados los habitantes encontraron seguridad y protección espiritual bajo el amparo de distintas advocaciones. La organización eclesiástica general que enmarcó a sus instituciones religiosas contribuyó también a forjar una imagen de las ciudades ubicándolas en un orden jerárquico que derivó de la preeminencia de unas sobre otras por tener la más alta dignidad eclesiástica, como cabezas de arzobispados, por haber sido designadas sedes de colegiatas, y poseer sus diócesis un patrimonio económico acrecentado con la dotación de rentas, bienes inmuebles, donaciones, compras e intercambios.

Otras imágenes presentaron a las comunidades andaluzas como paradigmas de comunidades cristianas. Esta idea se fundó en su misión evangelizadora, precursora en España y continuadora en América, y en la defensa de la fe católica frente a otras confesiones, y no pasó desapercibida en tiempos en que el ideal de unidad religiosa había comenzado a hacerse realidad en España. Especialmente Andalucía, identificada con el predominio judío-converso, el problema de la apostasía y la presencia de moriscos y alumbrados exaltó esos valores mostrando en los autos de fe, los progroms, la quema en vivo o en efigie o el castigo de individuos no católicos, la firme voluntad de imponer la autoridad de la Iglesia Católica y romper con la coexistencia pluri-religiosa.

Las acciones caritativas y piadosas con desvalidos, pobres y necesitados, a través de limosnas, donativos y la fundación de cofradías e instituciones hospitalarias configuraron el repertorio de virtudes ciudadanas. Si cabía alguna imagen negativa de las ciudades debido a la presencia de grupos marginales, ella se contrabalanceó con la exaltación de las generosidades de los habitantes que redundaban en mayor gloria para ellos y las ciudades. De esa forma, las historias mostraron una imagen coherente por la estrecha relación entre cultura religiosa y prácticas asistenciales.

En el imaginario social, las ciudades andaluzas se convirtieron en "entidades diferenciadas y privilegiadas por Dios" con numerosos ejemplos de santidad de época romana, visigoda e islámica. El prestigio y jerarquía que adquirieron las ciudades procedió además de la posesión de reliquias. En sintonía con las doctrinas del Concilio de Trento, la Iglesia y las prácticas religiosas de la cultura popular andaluza diversificaron y multiplicaron las posibilidades de sacralización del espacio rural y urbano elevando el status de los distintos lugares que se creía conservaban la "presencia tangible" de la Virgen y los santos, creándose además numerosos centros cultuales vinculados a las apariciones del más allá, la inventio y la translatio de imágenes y reliquias santas. Por otra parte, las ciudades potenciaron su importancia fundándose en los milagros que acreditaban el contacto entre el cielo y la tierra, mostrando sus permanentes vínculos con los santos. Particularmente estos asumieron un papel 
histórico de primer orden, pues concebidos como "hijos e ilustres ciudadanos", hicieron triunfar el cristianismo en sus patrias, las ciudades, situándolas en la Historia Sagrada.

Pero si unos quisieron asimilarlas con el máximo referente, la Civitas Dei en la tierra y buscaron reproducir y difundir ese modelo, otros elaboraron otras imágenes estereotipadas y menos favorables, con una mirada crítica sobre la Iglesia y las prácticas religiosas populares devido a la excesiva ritualidad para comunicar la piedad exteriormente.

\section{ESPACIOS Y TIEMPOS DE LAS FIESTAS}

Las comunidades urbanas expresaron ritual, social, económica, política y culturalmente formas de sociabilidad que las identificaban, convirtiendo a las ciudades en espacios simbólicos, lúdicos y festivos, en escenarios abiertos para la comunicación y el intercambio, en centros integradores de sus habitantes y de los entornos comarcanos. La fiesta cívica funcionó como instrumento formador de la memoria y conciencia histórica de las comunidades, de reafirmación del poder real en todo el territorio y renovación anual de sus lazos. Las celebraciones vinculadas a los ciclos de la vida familiar monárquica (bodas, nacimientos, bautismos, exequias fúnebres) que eran hitos fundamentales para su estabilidad, continuidad y fortalecimiento y las entradas reales constituyeron situaciones específicas en las que se desarrolló un protocolo pautado para que comportamientos y sentimientos de las sociedades urbanas se cumplieran en sintonía con los intereses de los monarcas. Pero también fueron ocasiones para la propaganda urbana, porque las oligarquías emplearon una serie de recursos para expresarse ritualmente en todos los niveles, comunicando una imagen ideal de sí mismas con la que deseaban influir ante los monarcas, y presentando una imagen teatral y utópica de sus ciudades que ocultaban el aspecto más deslucido y negativo de la "ciudad real" tras la "ciudad efímera", recreada circunstancialmente para transmitir imágenes del orden social y urbano, por medio de un decorado arquitectónico, técnico e iconográfico cada vez más complejo.

Las actividades lúdico-festivas inherentes a la cultura nobiliaria recrearon en las diversiones y entretenimientos unos ejercicios que influyeron en la educación, formación e instrucción de quienes practicaban el arte de la guerra. Rehabilitaron ideales caballerescos haciendo que los hombres aprendieran a respetar las reglas y ejercitaran cualidades y virtudes como la obediencia, la paciencia, la perseverancia, la fortaleza, la audacia, la justicia, la templanza, la destreza, modelando así no sólo el cuerpo, sino el espíritu. Las actividades recreativas populares mantuvieron con las anteriores algunos rasgos comunes: el mismo gusto por el gasto, el consumo y las ostentaciones. Influyeron también en el disciplinamiento de los habitantes, pues alegrías y diversiones honestas y saludables eran necesarias y recomendables como formas de sociabilidad que contribuían a fortalecer la paz, el orden y la cohesión de las sociedades urbanas.

Las actividades lúdico-festivas fueron formadoras de opinión de la imagen de las ciudades. Especialmente Jaén basó su fama y renombre en las fiestas organizadas por Miguel Lucas de Iranzo, que en los años sesenta del siglo xv la convirtió en 
centro de atracción de gentes de distinta procedencia debido a las generosidades y dádivas acostumbras por el condestable. Asimismo las fiestas incidieron en la construcción de imágenes de los ciudadanos andaluces. En juegos, torneos, los linajes nobiliarios exhibieron sus virtudes y sus símbolos de clase, pero también sus vicios porque sacaron a relucir las divisiones, tensiones, el espíritu de competencia entre los bandos-linajes. En esos casos, lejos de prevalecer la paz, el orden, el encuentro pacífico y la armonía, las fiestas se convirtieron en ocasiones para prolongar las luchas políticas. Lejos de "ennoblecer" a las ciudades donde se organizaban, haciendo trascender la fama de los protagonistas de los juegos y competencias, mostraron la otra cara de la moneda, menos positiva y modélica de la nobleza. El hecho de que intervinieran reyes, corregidores y otros representantes de la justicia o que se prohibieran o limitaran los juegos, muestra que la fiesta dejaba de ser percibida como espacio y tiempo apacible y alegre, como paradigma simbólico de la cortesía y de las virtudes de la nobleza.

Las fiestas religiosas fueron contempladas también como expresiones de la cultura urbana, de las creencias de los habitantes, como demostraciones de las relaciones particulares que las sociedades cristianas entablaban con Dios y lo sagrado. Pese a que los calendarios litúrgicos nos presentan un variado panorama sobre sus celebraciones, otras fuentes seculares y eclesiásticas nos ofrecen la contra-cara en la que puede advertirse que el cumplimiento de los actos litúrgicos y religiosos no fue siempre constante. La principal preocupación se centró en hacer efectivo el cumplimiento del precepto dominical y de las fiestas de guardar -como se desprende del contenido de los sínodos y las ordenanzas municipales que remarcaron la obligatoriedad de asistir a misa, confesarse, comulgar y concurrir a los actos religiosos y procesiones más importantes-, y en convertir a las ciudades en centros religiosos, no sólo reuniendo a sus habitantes, sino convocando y atrayendo a los que vivían fuera de su recinto murado, en sus términos o alfoces.

Dos grandes celebraciones escaparon a la indiferencia y se convirtieron en las más participativas y solemnes: la Semana Santa y el Corpus Christi. Ambas desplegaron un espectáculo visual, auditivo, emotivo, devocional y propagandístico, para difundir una "catequesis ambulante", transformándose en signos diferenciadores de la Europa protestante. Aunque suponían para los municipios y las cofradías cuantiosos gastos para financiar entremeses o representaciones, juegos, danzas, música y diversiones, posibilitaban a las ciudades adquirir fama, si el prestigio de sus fiestas religiosas trascendía más allá de sus murallas, atrayendo a la gente de las comarcas vecinas y villas cercanas.

\section{RET ORNOS AL PASADO. ORIGENES MITICOS Y RECUERDOS DE ROMA}

Las ideas-imágenes de las ciudades también se construyeron recurriendo al pasado, a los primeros tiempos y a la antigüedad clásica. Los historiadores pusieron el acento en el origen, en las leyendas fundadoras y en sus héroes bíblicos, míticos o históricos para basar en ellos la antigüedad de las ciudades; hicieron buen uso de la etimología de sus espacios geográficos para avalar sus calidades y excelencias; 
buscaron en los grupos humanos que las habitaron las pruebas de su valor civilizador e histórico y los fundamentos de su nobleza. Los que buscaron elevar la calidad, jerarquía y dignidad urbana, así como su historia, trataron de asimilar a las ciudades a la antigua Roma que había sido caput mundi, el principal arquetipo para construir representaciones ideales

En la antigüedad encontraron un pasado glorioso, movidos por la nostalgia, por la conciencia de su potencia o de su decadencia. Especialmente los historiadores, trayendo a la memoria antiguos títulos intentaron restablecer y restaurar la condición privilegiada de las ciudades en un nuevo contexto. En la antigüedad, nobleza y en los privilegios se basaron para realizar comparaciones entre ciudades, para dirimir sus competencias por la preeminencia, para solicitar privilegios o para confirmarlos. De manera que la construcción del pasado de cada una de las ciudades era también proyección de ese pasado hacia delante y entrañaba cierto interés por el futuro.

\section{CONCLUSIONES}

La historia cultural con sus nuevos métodos, y la ampliación de las fuentes hace posible analizar diferentes concepciones sobre las ciudades andaluzas desde una perspectiva integradora y global y ver en ellas tanto aspectos comunes a todas, por su pertenencia al mismo espacio regional, como rasgos específicos y particulares de lo local. Así se ha podido ver de qué manera la sociedad andaluza percibió la cultura urbana, de qué forma la interpretó y le dio sentido. Por otra parte, el análisis de las relaciones culturales, económicas, sociales, religiosas y políticas ha ayudado a hacer que lo urbano sea más legible y pueda definirse según prácticas, costumbres, ideas, creencias. Por consiguiente, las representaciones de las ciudades se muestran como un fértil campo de estudio, dejan ver al espacio urbano como generador de imaginarios, como lugares de producción de significados, como escenarios de actos representacionales, como espacios donde se desarrollaron concepciones, usos, costumbres y prácticas, todos ellos elementos constitutivos de sus identidades. Asimismo han permitido reconocer modelos alternativos de ciudades y cultura urbana, y aspectos de los modelos dominantes. 